\title{
У IMPERIAL AND LOCAL: AUDIENCE AND IDENTITY IN THE IDRIMI INSCRIPTIONS
}

\author{
Jacob Lauinger \\ Johns Hopkins University
}

\begin{abstract}
This article studies the Idrimi inscription from ancient Alalah, modern Tell Atchana, in order to explore how and to what effect manifestations of empire may have been socially consequential to local populations ruled by Mittani. Specifically, the article argues that Idrimi is presented as a Mittani hero, but the story of his life is told in a Northwest Semitic-Akkadian code; an imperial vision receives a local expression. From this conclusion, the article ends by trying to infer something about the inscription's intended audience.
\end{abstract}

The study of local or provincial elites in the empires of the ancient Mediterranean world and the Middle East is well-developed and has stressed the ideological dimensions of the formation and perpetuation of local elite identities. ${ }^{1}$ While work on the Mittani Empire, a Hurrian-speaking polity that controlled a great swath of northern Iraq and Syria, from the Zagros mountains in the east to the Mediterranean in the west, in the fifteenth and fourteenth centuries $\mathrm{BC}$, has tended to focus primarily on this empire's political dimensions, recent years have seen scholarship increasingly

1 For instance, Ando (2000) has argued that the Roman empire's remarkable stability depended, in part, on convincing provincial elites to share in a particular, constructed worldview; in the other direction, Brown's (2018) study of dining practices in the Iron Age kingdom of Edom demonstrated how local elites under Neo-Assyrian hegemony used foodways to connect themselves to local traditions and distance themselves from imperial ones.

I am grateful to Gina Konstantopoulos for the invitation to participate in the conference from which this article derives and to the other conference participants for their questions, comments, and conversation. Bibliographic abbreviations follow the CDLI Abbreviations for Assyriology <cdli.ox.ac.uk/wiki/abbreviations_for_assyriology> (accessed December 9, 2019) with the following addition: SSAU 2 = Dietrich \& Loretz 1969. With regard to my use of the plural "inscriptions" in the title of this article and throughout, the Statue of Idrimi (introduced in more detail below) has one inscription of 101 lines carved on its body and another inscription of three lines carved on its cheek. Conventionally, the text of the second inscription is treated as a continuation of the text of the first and placed at its end with the line numbers 102-104. However, as I have argued (Lauinger 2019; also discussed in more detail below), the inscription on the cheek serves to frame the inscription on the body and therefore should be understood as distinct from it. Therefore, I refer to these inscriptions separately as "the body inscription" and "the cheek inscription"; I follow the conventional lines numbering of the body inscription; for the cheek inscription, I use the line numbers CI 1-3. In contrast to my distinguishing between the two inscriptions, I use the term "text(s)" to refer to the composition more generally, with the parenthetical plural acknowledging that the body inscription and the cheek inscription may have been read together or independently in antiquity. I use the term "narrative" to refer to the firstperson account of Idrimi's life found in 11. 1-91.

Volume 9(2) (2021), pp. 28-46

DOI $10.23993 /$ store. 88220

Licensed under Creative Commons 4.0 (CC BY-NC-SA 4.0) license.

ISSN: 2323-5209

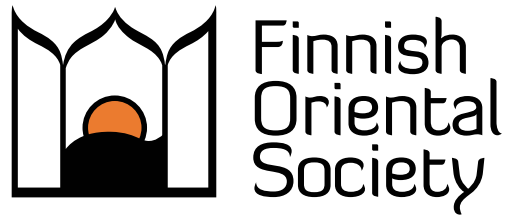


address ideology as well. ${ }^{2}$ In this article I attempt to contribute to this growing body of literature by considering the ideological dimensions of local, elite identity in the western reaches of the Mittani Empire. I do so by exploring how local, elite identity was conceived and expressed in the two inscriptions on the Statue of Idrimi from the Late Bronze Age city of Alalah, modern Tell Atchana, because these inscriptions, as argued in more detail below, are text(s) that were intended for consumption by an audience of local elites and therefore have the potential to reflect that audience's ideology.

One reason why the ideology of local elites is of interest is that Mittani's political involvement in its imperial periphery seems to have been characterized by a mix of top-down and bottom-up approaches. For instance, while the Mittani Empire controlled much of northern Iraq and Syria for about two centuries, it has become increasingly clear that its control over this area was not uniform but relied upon different modes. For instance, at Alalah, the city at which the Statue of Idrimi was found, local kings, Idrimi and his successors, swore oaths of allegiance to the Mittani emperor. However, at Halab, modern Aleppo, only about $80 \mathrm{~km}$ to the east of Alalah, the Mittani emperor replaced the local dynasty with a provincial governor (halzuhlu; see von Dassow 2014: 20 n. 27 for a discussion of this word). And at Bașiru, modern Tell Bazi, on the Upper Euphrates, the empire and its agents interacted not with a vassal king or governor but with the city's citizenry, most likely through some form of assembly (see, e.g., Sauštatar's grant of a town directly "to the sons of Bașiru"; DUMU.MEŠ uru $b a_{2}-s i_{2}-r i, Z A 9678$ obv. 3). ${ }^{3}$

Alongside these different modes of political control, there were also different degrees of citizenship and belonging throughout the Mittani Empire. For instance, generally the populace at any given city owed taxes and labor to the city's ruler or governing assembly. However, some residents possessed Hanigalbatūtu, or "Hanigalbat-ness" (see, e.g., AlT 13 [31.1], in which a resident of Alalah loses litigation against Niqmepa, Alalah's king, "about his Hanigalbatness" (aš-šum ha-ni-gal-ba-tu-ti-šu, obv. 4) and so "is returned to the (political) servitude of Niqmepa" (a-na $\mathrm{IR}_{3}{ }^{t i}$ ša ni-iq-me-pa it-tu-ur, rev. 11-12; see Niedorf 2008: 239-244 for an edition and commentary)). This abstract noun, which is built off of the toponym Hanigalbat, an alternative name for Mittani, signified that these individuals were citizens of the empire, not a local polity, and so they seem to have been exempt from some local taxes. ${ }^{4}$

Perhaps the best example of Mittani's mixing of top-down and bottom-up approaches to its empire is manifest in the quadripartite scheme of social classification that is found at opposite ends of the Mittani Empire, at Alalah and Nuzi. As von Dassow (2014: 26) has emphasized, the fact that this same quadripartite scheme is found at both Alalah and Nuzi means that the social classes "owe their creation and implementation to deliberate Mittanian policy, rather

\footnotetext{
2 See, e.g., Schwartz (2014: 270-271), who noted that "the role of southern Mesopotamia as a model to be utilized in the legitimization of Mittani rule seems relatively muted," even though "Babylonia was a traditional source of cultural and ideological models and technologies [...] in the Middle Bronze Age." In a comprehensive study of Mittani paleography, Homan (2020) has explored the relationship between writing and identity in cuneiform texts written under Mittani hegemony, including some produced in the Mittani imperial chancellery and others written at Nuzi, a third-tier site in the far eastern regions of the empire. I consider the polity named Mittani to be an "empire" on the basis of comparison to its peer polities, Egypt and Hatti, which are commonly described as such; cf. Cancik-Kirschbaum, Brisch \& Eidem 2014: 4: "[T] he use of the term empire should be linked to this notion of "extended power-relations"” (italics in original).

3 For a more comprehensive survey of the evidence for all three forms of political control, discussing these examples and others, see von Dassow 2014: 15-21; see also de Martino 2015: 27; 2018: 41.

4 Again, for a more comprehensive survey of the evidence for different degrees of citizenship under the Mittani empire, discussing this examples and others, see von Dassow 2014: 23-26; see also de Martino 2015: 28; $2018: 43$.
} 
than representing the outcome of an organic development." Yet the terminology used for the four social classes differs between the two sites. A member of the highest social class, the nobility, was called a maryannu at Alalah but a rākib narkabti 'chariot rider,' at Nuzi. ${ }^{5}$ The professional class known at Alalah as ehelle, or 'saved' in Hurrian, was known by a different Hurrian term at Nuzi, nakkušše, or 'released.' Members of the hupšu class at Alalah were the small landowners whose defining feature was their requirement to perform a labor service for the state; members of this class at Nuzi were known as älik ilki 'doer of $i l k u$ service.' Finally, members of the lowest class, tenant farmers, were called haniahhe at Alalah, a Hurrianized word perhaps deriving from Semitic words for 'tent' or 'weak;' they were known at Nuzi as the ašš $\bar{a} b u$ 'residents.'

Von Dassow (2008: 356) was well aware of the significance of the fact that the same social classes are designated by different terms at Alalah and Nuzi, as she ended her comparison on the topic by asking:

But who chose these terms, and on what basis? Was each set of class designations current in the vocabulary of each realm's population? This seems unlikely for the Akkadian terms, especially at Alalah. Were they chosen by the administration of each realm, or by their agents, the scribes who wrote the tablets that provide us with our only evidence for the existence of these classes?

In her explicit rejection of the first scenario but not the second, one suspects that von Dassow favored the latter, so that in the system(s) of social classification at Alalah and Nuzi, we see a mixing of top-down and bottom-up approaches in which imperial vision was made manifest in the outer marches but allowed a local expression.

The central interest of this paper is in exploring these topics-top-down and bottom-up approaches to empire, the local expression of imperial control-further but from an ideological perspective. Specifically, I am asking: How did elites in the peripheral regions of the Mittani Empire see themselves? Did they ascribe to an imperial ideology entirely? Did they maintain local traditions? Or do we see a mixing of imperial and local in their self-presentation? The Idrimi inscriptions are a good source for considering these questions, for they were created and displayed at Alalah and so were intended for consumption by a local audience. Therefore, we can hope to glimpse that audience's values in how the text(s) rhetorically position themselves. First, of course, we need a more definite idea of who, in fact, comprised the audience of the text(s), and so I begin this paper by marshaling evidence that identifies it as the nobility of Late Bronze Age Alalah (i.e., the local elites). After identifying this audience, I move onto the narrative's portrayal of Idrimi and demonstrate that it presents him as a maryannu, a hero at home in the courts of the Mittani Empire. Next, I shift from the content of the text(s) to their language, and, specifically, to recent work by Kathryn Medill (2019), which shows that this language is best described as a Northwest Semitic-Akkadian code. At this point, we are left with an unexpected juxtaposition: the Idrimi inscriptions portray a Mittani heroic ideal but express this ideal by references to West Semitic and not Hurrian. This juxtaposition, in text(s) intended to appeal to local elites on the periphery of the Mittani Empire, gives us valuable insight into the men who had influence in this empire's western reaches: they stood self-consciously with one foot

\footnotetext{
5 The writing maryannu normalizes the word with an Akkadian case vowel. On the word's etymology and the conceptual suitability of the translation "nobility," see von Dassow 2008: 96-97 and 280-283, respectively.

6 For more detailed comparisons between the terminology used for social classes at the two sites, see von Dassow 2008: 351-356; 2014: 26-28.
} 
in its imperial traditions and the other in the local traditions of home. Accordingly, the Idrimi inscriptions seem to imply a similar mixing of top-down and bottom-up approaches to local, elite identity under the Mittani Empire, as has also been seen in its different forms of political control, degrees of citizenship, and social categories.

Before getting into this paper's argument in detail, however, some background on Idrimi, the statue, and the text(s) is in order, in part because the argument presented here builds on recent work that I have done on these subjects. As mentioned above, the Idrimi inscriptions get their name first, from the fact that our sole exemplar of the text(s) is inscribed in Akkadian cuneiform on a statue; and, second, from the fact that the text(s) give a first-person account of the life of a certain king named Idrimi. This Idrimi was in fact a historical personage who ruled Alalah in the early part of the Late Bronze Age, around 1450 BC (von Dassow 2008: 33-35 discusses the textual evidence for Idrimi apart from the statue's inscriptions). The statue and its inscriptions, however, probably date to after this time, most likely to a span from 1400-1350 BC (Fink 2010; Lauinger 2019: 36-38 reviews the three primary arguments that have been put forward for the statue's date); stratigraphically, this time period is Woolley's Level III(/II), Level IVB (Fink 2010), or the current excavation's Period 3 (Yener, Akar \& Horowitz 2019). It is important to emphasize, though, that during this entire span, from 1450 (the approximate date of this historical Idrimi) to $1350 \mathrm{BC}$ (the approximate latest date for the statue), the kingdom of Alalah continuously acknowledged the hegemony of the empire of Mittani. ${ }^{7}$

As I have emphasized above, there are not one but two different inscriptions carved on the statue, although these inscriptions have conventionally been treated as a unit in the scholarship: a three line inscription is carved on the statue's cheek and beard, and a 101-line inscription is carved on the statue's body. The longer inscription on the body opens by introducing Idrimi and narrating how he, the youngest son of the king of Aleppo, was forced to flee that city with his family to Emar on the Euphrates. After sojourning at Emar, Idrimi traveled back west, this time crossing through the desert and traveling into Canaan. There, in the city of Ammiya, he rallied an army of refugees from his father's old kingdom and, after receiving signs from the Storm God, sailed with his soldiers up the coast of the Mediterranean and landed in front of Mount Hazzi, modern Jebel Aqra/Kel Dağ 1 , which lay at the southern point of the territorial kingdom of Late Bronze Age Alalah-Mukiš. According to the narrative, Idrimi was welcomed by the kingdom's inhabitants and reunited with his brothers. Having settled in the city of Alalah, Idrimi then sent an envoy to Parratarna, king of Mittani, and convinced this regional overlord to accept him as a vassal. Having established peace with the mighty king of Mitanni, Idrimi subsequently raided Hittite settlements in southern Anatolia - presumably with the king of Mittani's encouragement. After returning to Alalah with booty from this campaign, Idrimi focused his attention on domestic affairs: building himself a palace, caring for the inhabitants of his kingdom, and attending to the cult. At this point, the narrative concludes and the body inscription moves onto curses aimed at anyone who would remove or alter the statue, and a request for blessings for a certain Šarruwa, who claims to be the inscription's author.

7 See von Dassow 2020: 196-199, 201-203 for a succinct explanation of the revised stratigraphy and a discussion of the few other extant textual sources, all external to Alalah, that mention Alalah or Mukiš and date to this period. 
The other inscription, the short one carved on the statue's cheek and beard, reads in its entirety: "I was king for 30 years. I wrote my toil on my[s]elf. May it encourage them (the descendants) so that they (the descendants) pray to me regularly." " This translation follows Durand (2011: 150) in interpreting the first precative verb ("May it encourage") as a form of tukkulu, as opposed to dagālu, as is found elsewhere in the scholarly literature. Not only does this interpretation avoid some grammatical difficulties that dagālu brings with it, ${ }^{9}$ the verb tukkulu also fits well with the statue's ancient Sitz im Leben, which is generally understood to have been an ancestor cult (see, e.g., Mayer-Opificius 1981: 289; Sasson 1981: 323-324).

In my own recent work on the statue and its inscriptions (Lauinger 2019), I focused on a different word in the cheek inscription, mānahtiya (1. CI 2). Building upon the suggestions of previous scholars, I noted that the use of this word to describe the narrative on Idrimi's body has the effect of framing that narrative as naru-literature, a modern scholarly designation for a Mesopotamian genre of pseudo-autobiography in which kings leave written accounts of their (mis)fortunes so that future generations can learn from their actions. Examining further attestations of mānahtu in the body inscription allowed me to determine the Idrimi's narrative's didactic message: legitimate rule of Alalah was possible only by acknowledging the hegemony of Mittani. Furthermore, I argued that the orthographic and paleographic variation that is rampant throughout the inscriptions and that has so frustrated modern readers was in fact a meta-discursive strategy aimed at displaying the erudition of the inscriptions' author, thereby emphasizing importance of the text(s)' didactic message. In sum, I concluded that in its framing and telling of the Idrimi's life, the Idrimi text(s) were making an argument that engaged deeply with contemporary politics.

An obvious but nonetheless important implication of this conclusion that I did not take up in Lauinger 2019 is, of course, that the text(s) must therefore have had a contemporary audience to which this argument was made. The first step to identifying this contemporary audience is to recognize that the discursive strategy employed by the text(s) and the meta-discursive strategy employed by the inscriptions are both anchored in the Mesopotamian cuneiform tradition. This recognition is significant. The intended audience for both the text(s) and the inscriptions must have had a relatively high degree of scribal training in order to be able to recognize the allusions to texts like the Cuthean Legend of Naram-Sin or the Epic of Gilgamesh and to appreciate the diversity of sign forms, archaic and contemporary, inscribed on the statue. Relatedly, as I have noted, while the Cuthean Legend of Naram-Sin or the Epic of Gilgamesh are not themselves attested at Alalah, "other scholarly materials, comprising lexical lists, incantations, omina, and hymns are known from the site at this time" (Lauinger 2019: 30 n. 28), so that it is clear

\footnotetext{
8 CI 1. MU 30.K[AM].MEŠ LUGAL-ku CI 2. ma-na-ah-ti-iara-na [U]GU-ia aš-tún -ur li-tak $k_{3}-k a l_{2}-s ̌ u-n u$ CI 3. $u_{3} a$-na UGU-ia li-ik-ta-na-ra-bu. For the reading [U]GU-ia in line CI 2, see Lauinger 2019: 29 n. 25.

9 For instance, Oller (1977: 18) understands a precative of dagālu and translates "Let one constant[ly lo]ok upon them (i.e., the inscribed accomplishments)." But the proposed referent for the $3 \mathrm{mpl}$ pronoun "them" (-šunu) is in fact singular (mānahtiya). The verb dagālu is also not used in Akkadian with the sense of looking at something in order to read it; that verb is amāru, "to see" (CAD A/2 s.v. amāru A mng. 3 gathers references from all periods of Akkadian). And for an impersonal subject, as found in Oller's translation, we expect a 3 m.pl. form, but the verb is singular.
} 
that more advanced scribal training in Akkadian and Sumerian cuneiform occurred at the city during the Late Bronze Age.

Having recognized that the inscriptions were written to appeal to a contemporary audience that had a relatively high degree of scribal training, the second step in identifying this audience then becomes a question of asking who had such scribal training at the time. Because of the paucity of Late Bronze Age texts that, like the Idrimi inscriptions, postdate the destruction of the Level IV palace, we will try to answer this question by looking at the somewhat-earlier Level IV corpus of texts that date to before the palace's destruction. Of course, this approach assumes that any answers we find in the Level IV corpus would be still valid for Alalahian society during the period of time after the destruction of the Level IV palace but before the Hittite conquest of the city (i.e., Woolley's Level III(/II), Fink 2010's Level IVB ${ }^{\mathrm{F}}$, or the current excavation's Period 3 (Yener, Akar \& Horowitz 2019)). However, this assumption seems warranted because "the end of Level IV" is in essence a statement about architecture and not one about social and political (dis)continuities. ${ }^{10}$ These discontinuities would be expected later, after the Hittite conquest.

When we talk about scribes and scribal training in the Level IV corpus, we need to acknowledge that we are dealing with a continuum. At the one end, we must imagine scribes who operated in institutional or non-institutional contexts and produced administrative texts in the course of tracking the receipt and disbursement of commodities. These activities would have required a relatively low level of literacy and numeracy and not necessitated any exposure to literary texts during scribal training. Looking at the Level IV corpus, we find one example of a scribe who seems to have belonged to the first group, a certain [PN], the son of Ewri-Kiaše, who was a member of the ehele social class and who is listed, identified by his profession, among leatherworkers, a cartwright, and other professional specialists in the census list AlT 153 [413.17] rev. 30 (= SSAU 233 ).

At the other end of the continuum, we must imagine individuals who were highly educated in cuneiform and who would have been familiar with the Mesopotamian literary tradition as a result of this education. While some persons located at this end of the continuum conceivably were "palace scribes," attached, for example, to a chancellery, who drafted treaties, royal inscriptions, and other prestige documents for the king, we might also find at this end of the continuum wealthy, high-status individuals who were not "employed" as scribes by anyone at all but for whom literacy and numeracy allowed them to pursue their business affairs (writing letters and contracts) and, just as importantly, afforded them cultural capital. And, in fact, the majority of the attestations of "scribe" in the Level IV corpus designate individuals in this second group, persons for whom the designation "scribe" seems to have been a hat they wore on occasion, not a profession that they pursued full-time.

For instance, in the legal text AlT 51 [352.6], the caption to the seal impression on the obverse of this text identifies the seal as belonging to an unnamed líGİR DUB.SAR. While the logogram ('iu)GÌR is often used to designate relatively low-level functionaries responsible for conveying goods from their place of disbursement to their place of final use, it does not seem to indicate such a role in AlT 51 [352.6]. As Niedorf (2008: 384) noted, the seal impression of this líGìR

10 "As Woolley defined it, Level IV begins with the construction of the palace that he attributed to Niqmepa, and it ends with the destruction he attributed to the Hittites under Šuppiluliuma I. The palace whose construction marks the start of Level IV was however destroyed long before the Hittite conquest that marks the end of Level IV" (von Dassow 2020: 196). 
is in the exact place on the tablet where typically the royal seal was impressed, meaning that the individual qualified as "í GìR DUB.SAR "als Stellvertreter des Königs die Rechtmäßigkeit des hier festgehaltenen Geschäfts garantierte" and so had "eine hohe administrative Stellung." Accordingly, Niedorf suggested that lí GÌR was an abbreviation for a longer logogram, such as l'GİR.NÍTA, šakkanakku, 'governor,' or l'GİR.ŠÈ.GA, sākinnu, 'prefect.' Moreover, this líGÌR DUB.SAR may not even have been the scribe responsible for AlT 51 [352.6]; ${ }^{11}$ if not, his decision to identify himself as a scribe nonetheless would be even more suggestive of how this qualification had meaning as a marker of identity outside of simple legal functionalism.

What about the other attestations of scribes in the Level IV corpus? Most of these attestations occur in the witness lists to legal texts (von Dassow 2008: 285-286 gathers the references) to designate the scribe who drew up the document. In these witness lists, the practice was for the scribe to list himself in final position, as was done in cuneiform legal texts from other times and places. The witness lists themselves generally comprise a small recurring group of individuals of high status, such as šukkallum-ministers, šangûm-priests, and hazannum-mayors, and one concurs with Niedorf's (2008: 144) impression "daß dieselben Männer der führenden Gesellschaftsschicht sich vor dem König gegenseitig ihre Geschäfte bezeugen.” For our purposes, the key observation when looking at these witness lists is that a particular individual sometimes functioned as the scribe for a legal text and other times simply acted as a witness within this circle of friends. We can illustrate this point with two examples.

The first example involves a certain Ašraqama. In the marriage contract AlT 91 [33.1]: 23, Ašraqama is attested as the document's scribe; ${ }^{12}$ other witnesses include persons named Agi- ${ }^{\mathrm{d} I M}$, Taguhli, and even Šarruwa, most likely the famous Level IV scribe, though not acting in such a capacity in this text. In AlT 67 [341.2]: 11, we also find Ašraqama in the witness list, again with Agi- ${ }^{\mathrm{d} I M}$ (now identified as a $\check{s}$ ang $\hat{u}$-priest) and Taguhli, but now not functioning as the document's scribe, who is instead a certain Tuppiya. Indeed, in this text, Ašraqama is listed as the very first witness, suggesting that he had a higher status than Agi- ${ }^{\mathrm{d}} \mathrm{IM}$ and Taguhule and that his position after them in the witness list of AlT 91 [33.1] was due only to his role as that document's scribe. ${ }^{13}$

The legal text AlT 74 [342.3] also introduces us to our second example of a high-status individual identifying himself as a scribe on some occasions but not others. This individual is a certain Biriyašura, who appears as a witness to four legal transactions. In these transactions, the creditor is either a father or his son, once a certain Tuttu (AlT 74 [342.3]) and three times his son Ilimilimma (AlT 48 [352.3]; AlT 49 [352.4]; AlT 70 [341.5]). Tuttu and Ilimilimma are two of the wealthiest and most important men attested in the Level IV corpus, with the son securely identified as a maryannu (Bunnens 1978; von Dassow 2018: 170, 294-297). In the earlier text,

11 Because the scribe responsible for a legal text typically appears as the final name in the witness list, the scribe of AlT 51 [352.6] was probably named Tu-[...] (). However, the lúGİR's seal inscription identifies its owner as $[Y]$ ana-[...]. Of course, it is possible that Tu-[...] used a seal that he had inherited, in which case he could be identified with the líGİR.

12 Because of Ašraqama's position at the end of the witness list, von Dassow's (2008: 278 n. 54) suggestion to read the profession following his name as DUB.SAR seems certain to me; cf. the readings SUKKAL, found in Niedorf 2008: 266; Dietrich \& Mayer 1996: 185; $\mathrm{E}_{2}$.[GAL.LI]M found in Na' aman 1980: 111.

13 These are the only three attestations of the personal name Ašraqama in the Level IV corpus, but the same individual may also be encountered in the solitary attestation of the name Ašriya (AlT 74 [342.3]: u.e. 19), possibly a hypocoristic of Ašraqama (von Dassow 2008: 285). Ašriya is the scribe of AlT 74 [342.3] and appears in its witness list in the company of a number of highly ranked individuals, so this identification, if correct, would add further support his own high status. 
AlT 74 [342.3], in which Ašriya (see note 13) is the scribe, Biriyaššura appears in the witness

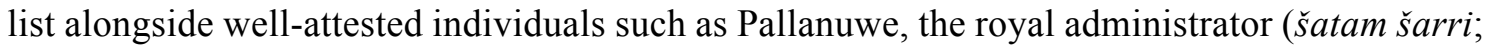
von Dassow 2008: 171), Irkabtu, "a prominent official with responsibilities for the army" (von Dassow 2008: 147), and Iri-Halba, who is known to have been a maryannu (von Dassow 2008: 390). In the three later texts, Biriyaššura appears consistently in the witness list with a certain Taguhli, who can be securely identified as a maryannu (von Dassow 2002: 844); another individual named Titiya also appears in two of the witness lists, but less is known about him). In two of these texts (AlT 49 [352.4], AlT 70 [341.5]), Biriyaššura is the scribe, but in one (AlT 48 [352.3]), he is not. Like Ašraqama, we encounter a situation where sometimes Biriyaššura takes his turn as the scribe responsible for a legal text but other times is just a witness.

But the most significant attestation of Biriyaššura has to be AlT 109 [2.6], a letter sent by the man himself to King Niqmepa (and so representing one of his earlier attestations, with AlT 74 [342.3] and AlT 353 [44: 15]). In this letter, Biriyaššura addresses the king by name, not title, and with a surprisingly familiar greeting formula: "Thus says Biriyaššura to Niqmepa: Live in good health! May your possessions be well!" ( $a-n a{ }^{\mathrm{m}} n i q_{2}-m e-p a$ um-ma ${ }^{\mathrm{m}} b i$-ri-a-sur-ru-ma

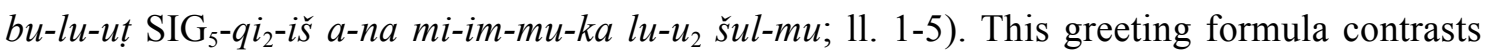
strongly with the note of deference that we expect an inferior would show in writing to his lord; compare, for instance, the opening of AlT 107 [2.4]: "Speak to the king, my lord! Thus says Ir-Teššub: (I fall) at the feet of my lord!" (a-na LUGAL ${ }^{r i}$ be-li-i $[a] q i_{2}-b i_{2}-m a$ um-ma ${ }^{\mathrm{m}}$ ir-te$\check{s} u-b a[(\ldots)] a-n a \mathrm{GIR}_{3}{ }^{p i_{2}}$ be-li-i[a]; 11. 1-4). Indeed, the contrast is so great and unexpected that von Dassow (2008: 286 n. 69) doubted that the sender of AlT 109 [2.6] could be the same as "the scribe Biriyaššura who was employed in Niqmepa's administration." But this doubt rests on the assumption that the authors of legal documents were "scribes" who were "employed" and so postulates another individual simply in order to fit this assumption. However, the name Biriyaššra is uncommon in the Level IV corpus (AlT 109 [2.6] is the only attestation besides the ones found in the witness lists and legal texts discussed above), and so it seems better to accept with Niedorf (2008: $40 \mathrm{n}$. 47) that the sender of AlT 109 [2.6] is the same as the Biriyaššura of the legal texts. Indeed, Niedorf suggests that the familiar greeting formula is evidence of "ein großes Vertrauensverhältnis, evtl. sogar eine enge Verwandtschaft" between Biriyaššura and the king.

Indeed, the fact that nothing that seems to distinguish those individuals who are sometimes qualified as scribes in legal texts and sometimes not from the elite individuals who appear as witnesses in the same lists suggests that the sometime-scribes were themselves members of Alalah's nobility and that scribal training was widespread among this class during Level IV. This suggestion is reinforced by several administrative texts in which many of these same men mentioned above appear together in groups in connection with some task they had in common, at least from the perspective of the royal administration. For instance, there is AlT 156 [415.5], an administrative text listing individuals associated with a temple of Kubi, in which we find both our sometime-scribes Ašraqama and Biriyaššura, as well as Iri-Halba, Taguhli, a šangĥu-priest, and two sons of a šukkallu-minister. ${ }^{14}$ AlT 353 [44.15], an administrative text listing individuals with and without sheep, includes our Biriyaššura as well as the

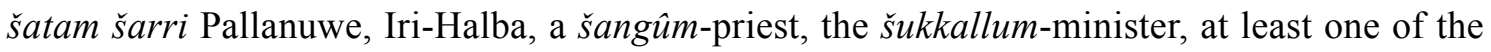

14 Von Dassow (2002: 856) notes that other names listed in the text "are attested elsewhere as names of members of the maryanni class," while cautioning that "some of these names, as well as additional ones, are also attested as members of the hupše class." 
šukkallum-minister's sons, and other high-status individuals known from other texts. As von Dassow (2002: 910-911) summarizes, "the men named in AlT 353 [...] evidently constituted a group of prominent residents of Alalah [...] who were closely associated with the palace. [...] It is tempting to suggest that AlT 353 records the distribution or collection of sheep on some particular occasion, involving important Alalahians." Finally, a number of these same men, such as the sons of the šukkallum-minister, and others that we have met in the legal texts discussed above, such as Ilimilimma and Taguhli, appear in a third tablet, AlT 128 [414.1], which lists maryannu who "were probably resident in the city of Alalah," some of whom "were also members of what could be called the royal court" (von Dassow 2002: 847).

This, then, is the picture we have of who possessed the ability to read and write Akkadian cuneiform during the second half of the fifteenth century BC (i.e., during Woolley's Level IV): occupational specialists on par with craftsmen such as leatherworkers and cartwrights, to be sure, but also the city's nobility, a wealthy, influential, and relatively closed circle of men. We are not always, or even usually, able to determine their social class, but when we are, these individuals are maryannu. And, as discussed above, there is good reason to think that this picture of cuneiform literacy is also applicable to the first half of the fourteenth century (i.e., Woolley's Level III(-II), the current excavation's Period 3, and the range of time into which the Statue of Idrimi and its text(s) need to be dated), because there is no reason to understand the transition from Level IV to Level III to have been accompanied by any political or social transformation, as Alalah continued to acknowledge the hegemony of Mittani during Level III until the second half of the fourteenth century. As discussed above, the Idrimi text(s) were written, at least in part, for a contemporary audience; the nobility of the early fourteenth century, who had the time and resources to enjoy a more advanced education in Akkadian cuneiform, represents the most likely audience.

Having identified a probable audience for the text(s), we are now in a position to explore how the text(s) rhetorically position themselves in relation to this audience because these positionings reflect the audience's values (or at least what the author of the text(s) expected those values to be). For instance, we have already seen such positioning to some extent in the meta-discursive role played by cuneiform and Mesopotamian learning in the Idrimi text(s) and inscriptions. In this section, I will argue that we can see another rhetorical positioning in the textual portrayal of Idrimi as hero. Significantly, in the narrative of his life, Idrimi is portrayed as a maryannu. Granting some level of audience identification, ${ }^{15}$ this portrayal can be seen as a rhetorical strategy, conscious or unconscious on the part of the author, to the text(s)' audience members, who would then have seen a reflection of themselves, or what they aspired to be, in the narrative's hero, which, in turn, would have encouraged their connection to the text(s).

However, the claim that Idrimi is portrayed as a maryannu in the text(s)' narrative deserves some support, because there is a half-century of scholarship which has found a home for the narrative of Idrimi's life-in which a younger son loses his home, sojourns far away, and wins a kingdom —in a Levantine, West Semitic-speaking literary context, with the inscriptions' most

15 The literature on audience identification is vast, spanning disciplines such as literary criticism, media studies, and psychology, among others, and so cannot be summarized here; for one theoretical framework coming out of the empirical study of literature, see Oatley 1994; 1999. 
cited parallels being found in the Hebrew Bible. For instance, in his review of Sidney Smith's (1949) original edition of the text(s), A. Leo Oppenheim (1955: 199) declared the narrative "without parallel in texts of this type from Mesopotamia and Egypt." He went on to conclude that the inscriptions "bespeak the existence of a specific literary tradition, totally different in temper and scope from that of the ancient Near East; of this tradition we have known only the later, far more substantial but equally admirable, fruits in the narratives of certain sections of the Book of Genesis and especially in the story of King David" (Oppenheim 1955: 200).

The comparison of Idrimi with David is by far the one most commonly met in the scholarship, but other comparisons have been made as well. To mention only two, in their edition of the text(s), Edward Greenstein and David Marcus (1976: 76-77) included an extended comparison with the story of Jephthah from Judges 11, and both Mario Liverani (1974: 439-440; see Liverani 2004 for an English translation) and Jordi Vidal (2012: 83) have pointed to the story of Joash in 2 Kings as a parallel example of, in Vidal's words, "the motif of the dynastic upheavals followed by the flight of the young hero."

We should be cautious, though, in attributing this type of story-what Edward Greenstein (2015) termed "the fugitive hero narrative pattern"- too readily with the Levantine world. In a perceptive study that acts as a critique to the universalizing approaches of the early twentiethcentury pioneers of narratology such as Lord Raglan, Joseph Campbell, and Vladimir Propp, as well as their inheritors, Greenstein identified the fugitive hero pattern in stories from Egypt, Hatti, and first-millennium Assyria and Babylonia. Rather than stressing the stories' similarities, Greenstein's interests lay in the opposite direction.

Beyond the shared structure, each fugitive hero narrative develops its own individual themes and objectives. In looking at a particular story, the variations on the pattern are especially significant and poignant. One is interested in seeing how each text departs from, adapts, or otherwise transforms the shared story pattern. (Greenstein 2015: 24)

With Greenstein, our interest is less in the fact that the Idrimi text(s) might share narratological features with other ancient Near Eastern texts and more in the text(s)' particularity. Before getting too deep into those particulars, though, we should briefly summarize previous work on the structure and function of the Idrimi narrative.

In this regard, it has long been recognized that the narrative portion of the Idrimi text(s) is itself comprised of two distinct sections that have a very different feel. The earliest statement to this effect known to me goes back to Jean Nougayrol's review of Smith's original publication, in which he described the first section as "le récit des faits qui ont précédé et déterminé son [=Idrimi's] avènement," and the second as "celui des événements marquants de son règne" (1951: 151; Nougayrol also acknowledged a third section that occurs after the narrative, "l'épilogue").

These two sections work together to create a whole that is greater than the sum of its parts. In the first section, Idrimi's status as a younger brother, his flight from Halab following a political crisis, a seven-year period of exile, and a divine encounter give the narrative "il carattere di 'prova' [...], prova che fa sì che il protagonista si qualifichi come 'eroe' (Liverani 1972: 412). ${ }^{16}$ Following this divine encounter, Idrimi seizes control of Alalah and the action of the narrative shifts. In short order, Idrimi engages in diplomatic negotiations, launches a successful military

16 In the article's English translation: "a kind of 'trial', permitting the protagonist to qualify as a 'hero"” (Liverani 2004: 94). 
campaign, commences building projects throughout his kingdom, and reestablishes the proper performance of religious rites. In other words, the narrative next lists the attributes of a good ancient Near Eastern king in its second section and demonstrates that Idrimi has checked each box. Or, as Gary Oller (1977: 193) described it, "the second section [...] is designed to show Idrimi as a good ruler, and hence presents further justification for his legitimacy."

At a functional level, then, we can see the work that the fugitive hero narrative pattern does in the Idrimi text(s). By casting Idrimi in the role of a fairytale fugitive hero, this narrative pattern functions as one strategy to justify a usurper king's rule. And this, of course, is the same function that the narrative pattern plays in many of the other texts in which it is found. But what about the specific manifestation of the pattern that we find in this particular narrative, the ways in which it "departs from, adapts, or otherwise transforms the shared story pattern," which Greenstein urged us to be sensitive to? In other words, if Idrimi is a fugitive hero, whose hero is he?

At this point, we should look more closely at the text(s), and, specifically, at one line. The line in question occurs fairly early in the narrative, following immediately upon a difficult passage in which Idrimi has an epiphany that prompts him to leave Emar and take up his adventure in earnest. The first part of that adventure will feature a night's stay in the desert, the liminal place that will transform Idrimi into the hero who will be subsequently recognized by his scattered countrymen in Canaan. But before he leaves Emar and enters the desert, the narrative pauses for Idrimi to note what he brought with him on his journey: "I took my horse,

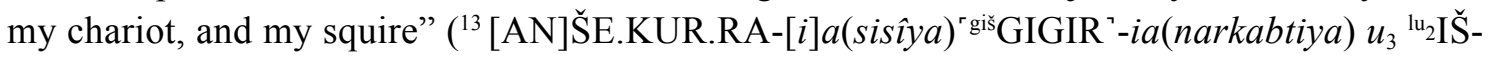
$\left.i a(k i z \hat{\imath} y a){ }^{14}[e l]-t e-q e_{2}-\check{s} u-n u\right) .{ }^{17}$

The details are striking in part because they are superfluous. As Jean-Marie Durand (2011: 156) has remarked, "Il est intéressant en tout cas de voir qu'il n'y a plus mention par la suite de ce kîzum[sic] (qui de toute façon reste pour nous un inconnu.)" ${ }^{18}$ Neither horse nor chariot reappear in the narrative either, ${ }^{19}$ and the plot could continue in exactly the same way that it does if all three

17 I restore the sign completely ([el]-) because I did not see any traces of it when I studied the statue. The sign appears undamaged in Smith's (1949: 14) edition (el-) and partly preserved in Dietrich and Loretz's (1981: 204) edition $([e] l-)$. Presumably its condition had already begun to deteriorate when Dietrich and Loretz studied it some thirty years after Smith, and it disappeared completely over the next decades. Despite being in the accusative case, the logograms are normalized with a case vowel in /i/ because they are followed by the $1 \mathrm{c}$.s. pronominal possessive suffix -ia, as is typical in Late Bronze Age dialects of peripheral Akkadian. The correct reading of the logogram 'í I $\breve{S}=k i z \hat{u}$ is, as Weeden (2011: 254) notes, "disputed. The readings kuš or šušs have both been proposed. .... As all evidence is currently ambiguous, the most logical course of action is to retain a transliteration LÚ IŠ." In texts from Late Bronze Age Anatolia and Syria-Palestine, the kiz $\hat{u}$ seems to designate the member of a chariot team, either the driver or archer, who accompanied a maryannu in combat. The translation of "squire" used here follows the suggestion of von Dassow (2008: 313) and is intended to encompass the fact that whether this person primarily held the reins or a bow, the vicissitudes of combat undoubtedly required that he perform the other function on occasion and that "off the battlefield" his "main task would have been the care and, probably, training of horses." For a careful discussion of the secondary literature, still up-to-date as of this writing, see von Dassow 2008.

18 Borger (1968: 22), followed by Dietrich and Loretz (1981: 204), suggested that the 3 m.s. pronominal suffix $-\check{s} u$ in line 16 in the clause $i \check{s}-t i-s ̌ u ~ . . . b i-t a_{2}-k u$ refers back to the kizûm in line 13 ("I spent with night with him"), but most scholars consider that it must refer back to the Suteans in the immediately preceding line 15, and emend the text to $i \check{s}-t i-s ̌ u-<n u>\ldots b i-t a_{2}-k u$ ("I spent the night with them"); see, e.g., Greenstein \& Marcus 1976: 73.

19 Smith (1949: 15) saw the chariot reappearing at the beginning of line 16, reading the partially preserved $\operatorname{sign}(\mathrm{s})$ there as [ $\left.{ }^{\text {gis }}\right]$ GIGIR. This reading was accepted by most scholars until the late 1970 s, when collations by Oller (1977: 10,34) and Dietrich and Loretz (1981: 204) established that the wedges in question are better read as ' $k u^{\prime}$ - (my collation of the sign agrees and could not find support for Durand's (2011: 137) most recent proposal to read $\left.\left[{ }^{\mathrm{g}}\right]^{\mathrm{s}} \mathrm{s} m a^{\mathrm{T}}-\right)$. 
were never mentioned. Still, though, of the three, the greatest surprise is the inclusion of the squire, for, in his seminal study already quoted above, Liverani (1972: 407) traced the appearance and reappearance of a literary motif across the Late Bronze Age in which "l'eroe è solo, sul carro, si avventura nel deserto." ${ }^{20}$ For Liverani (1972: 404-405), this motif functions "sempre ovviamente con l'intento generale di mettere in risalto la valentia dell'eroe per mezzo del suo isolamento."21 The Idrimi narrative is a key text for Liverani in this argument, yet oddly he never engages with the appearance of Idrimi's squire in this line. Still, one wonders if the squire's presence bothered Liverani at some level, for in one telling moment in the essay, he elides the squire completely, translating the line: "Presi il mio cavallo ecc" (Liverani 1972: 407). ${ }^{22}$

However, I do not think the presence of the squire invalidates either Liverani's identification of the motif in the Idrimi narrative or the significance that he attributes to the hero's solitary state. Rather, following Greenstein's maxim (quoted above), let us instead focus on the particularity of the motif in these lines. That is, if Idrimi is being cast in the role of a solitary questing hero, why does the narrative make sure that we know he was accompanied by his squire?

An answer to this question lies in the work that this line does not so much in propelling the narrative forward but rather in giving Idrimi a social and political identity. In this answer, I am taking up an observation of Durand (2011: 115), who has remarked that "[1]e fait qu'ldrimi parte avec son char et son palefrenier reflète certainement [...] qu'il avait [...] un statut de maryânu." As mentioned at the start of this article, the term maryannu designates a social class. It was the object of extended study by von Dassow (2008: 268-314) as part of her work on social stratification at Late Bronze Age Alalah, from which she concluded that " $[\mathrm{t}] \mathrm{he}$ class denoted maryann $[u]$ was formed of elite members of society, and its most characteristic feature was the use of horse-drawn war chariots" (von Dassow 2008: 268).

In the course of arriving at this clear and concise statement, von Dassow had to dispel many of the myths about maryannu that can be found in earlier literature. At the risk of reviving them here, these myths include a posited connection of maryannu with Indo-Aryan ethnicity (von Dassow 2008: 87-90), that the maryannu class represents some development of "a caste of noble chariot warriors into a class of wealthy landowners" (von Dassow 2008: 290), or that owning a chariot was a prerequisite for being a maryannu (von Dassow 2008: 300-304). Nonetheless, von Dassow's methodical examination of the evidence also makes it clear that a close association existed between the maryannu and the chariot: for instance, even if a maryannu did not need to possess one to belong to the social class, census lists from Late Bronze Age Alalah show a careful concern in documenting whether or not individual maryannu possessed them at the moment of the texts' composition (von Dassow 2008: 303-304); other administrative tablets "provide evidence that the palace supplied chariots, as well as horses, to members of the maryann [u] class" (von Dassow 2008: 309); furthermore, as mentioned above, the analogous class to Alalah's maryannu at Nuzi were designated rākib narkabti 'chariot rider,' so that the chariot is literally written into the social class's name.

\footnotetext{
20 Liverani 2004: 89: "[T] he hero is alone, on a chariot, and ventures into the desert."

21 Liverani 2004: 87: "[T] he general purpose always is to emphasize the hero's valour by pointing out his loneliness."

22 Liverani 2004: 89: “(So) I took my horse, etc.” See Klengel (1981: 274), who describes Idrimi as leaving "mit [...] nur einem Begleiter," yet refers to the passage as "ein Topos der syrischen Erzählliteratur," citing Liverani's 1972 essay. Elsewhere in the essay, Liverani (1972: 404) describes leaving with the horse, chariot, and squire as leaving "con accompagnamento strumentale ridotto al minimo indispensabile" (Liverani 2004: 87: "with minimal equipment"), a description with which, as discussed below, I agree.
} 
Interestingly, some of the same census lists documenting maryannu and their chariots also list individuals who are identified as kiz $\hat{u}$, "squires." Significantly, these squires are generally qualified as belonging to someone, usually the king. As von Dassow (who considers the kiz $\hat{u}$ to have been the charioteer; see note 17) concludes:

[W]hile a maryann $[u]$ could employ his own kizû, the royal administration, in the person of

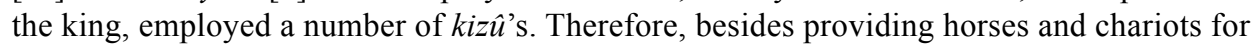
maryann $[u]$ serving in the chariotry, the administration could also have provided them with chariotdrivers if $[\ldots]$ they had no kizh of their own. Each maryann $[u]$ who went to war would set forth with his horse(s), his chariot, and his kiz $\hat{u}$, like Idrimi in the passage of the statue inscription that describes its hero setting out on his quest for kingship. (von Dassow 2008: 314)

Thus, the squire, together with the horse and chariot, represents simply one more piece of Idrimi's professional accoutrements so that, far from starting his adventure with an unexpected companion, Idrimi remains as solitary a figure when he leaves for the desert as the other heroes whom Liverani (1972) studied. As for the question posed above-if Idrimi is a hero, whose hero is he?-it seems clear now that Idrimi represents a heroic ideal at home in the courts of the Mittani Empire.

At this point, one might object that this depiction of Idrimi portrays him only generally as a chariot-driving aristocrat and not specifically as a Mittanian chariot-driving aristocrat. However, as discussed above, in text(s) written under Mittanian hegemony and arguing for "the desirability and even necessity of Alalah's political subordination to Mittani" (Lauinger 2019: 34), it is hard to imagine that a contemporary audience could see Idrimi as anything other than a maryannu in this portrayal. Indeed, Idrimi's story may have had a special resonance in the literary traditions of the Mittani court, as we can see if we look away from it for the moment and instead to EA 17, a letter sent by a king of Mittani, Tušratta, to the Egyptian Pharaoh Amenhotep III shortly after the Mittani king had been crowned, which Mario Liverani (2001) has fruitfully compared to the Idrimi narrative.

As usual for diplomatic letters between the so-called Great Powers in the Late Bronze Age, EA 17 begins with formulaic greetings and ends with details about the greeting gift accompanying the missive and request for a response. In between, however, Tušratta offers the Egyptian Pharaoh a condensed version of his life story. The story begins:

When I sat on my father's throne, I was young and Pirhi had done an evil deed to my land, (namely), he had killed his lord. Because of this, he did not allow me an alliance with one who loved me. But as for me, I did not act negligently concerning these evil deeds that were done in my land. I killed the men who murdered my brother Artaššumara together with their followers. ${ }^{23}$

At this point, Tušratta pauses in his narrative to remind the Egyptian pharaoh of the past alliance that existed between his (Tušratta's) father and the pharaoh:

Because you were allied with my father, so I have sent a message concerning this and reported (it) to you so that my brother (i.e., Amenhotep III) will hear them (i.e., the messengers) and rejoice.

\footnotetext{
$23{ }^{11} i \check{s}$-tu i-na giš GU.ZA ša a-bi-ia $u_{2}-s ̌ i-b u{ }^{12} u_{3}$ șe-eh-re-ku $u_{3}{ }^{\mathrm{m}}$ pir-hi a-ma-ta ${ }^{13}$ la ba bai-ta a-na KUR-ti-ia $i$-te-pu-uš-ma ${ }^{14} u_{3}$ be-el-šu id-du-uk $u_{3}$ aš-šum an-ni-ti ${ }_{3}{ }^{15}$ ia-ši it-ti ša i-ra-'a-ma-an-ni-ni ța-bu-u- ${ }_{2}$-ta ${ }^{16}$ la $u_{2}$ ma-aš-ša-ra-an-ni $u_{3}$ a-na-ku ap-pu-na-ma ${ }^{17}$ aš-šum a-ma-a-ti an-na-ti $i_{3}$ la ba $a_{2}-n a-a-t i_{3}{ }^{18}{ }^{18} a$ i-na KUR-ti-ia in-

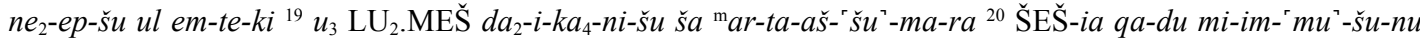
$a d-d u-u k-\check{s} u-n u-t i$.
} 
My father loved you, and as for my father, you, moreover, loved him. My father gave my sister in marriage to you out of love. Who el[se] was (there) who was like you with my father? ${ }^{24}$

After this recapitulation of the earlier alliance, the young king of Mittani returns once more to his narrative:

By the life, moreover, of my brother, when the land of Hatti returned against me in its entirety, when the enemies came to my land, Teššub, my lord, placed it (i.e., Hatti) in my hands, and I killed it. There was not one among them who (came) from his land that returned. Now, I have sent you one chariot, two horses, one boy, and one girl who are plunder (captured) from Hatti. ${ }^{25}$

The description of this victory over the Hittites ends the body of Tušratta's letter.

Even though, from the perspective of genre, the diplomatic letter and the royal inscriptions on a statue are quite different, the texts are remarkably similar in their narrative arcs:

Every single feature in the story has its parallel in the Idrimi inscription: the trouble (or coup d'état) in the father's house, [...] his young age and the contraposition to his brother(s), the bold action to recover the throne, the eventual confirmation of his military attitudes by beating the external enemy (the Hittites in both cases!), his sharing of the booty with friends. (Liverani 2001: 305)

Indeed, the similarities between the Idrimi inscription and the letter of the young Tušratta are so close that Liverani postulated that:

[the] letter seems to be the epistolary version of an official report on Tushratta's enthronement, a report emphasizing the heroic qualities and accomplishments of the young king in order to demonstrate his attitude to rule, thus overcoming the problem (deeply felt by the inner public opinion) of the irregular and violent origin of his reign. We could even try to write a "Tushratta statue inscription," using the Idrimi text as a model-frame [...] (Liverani 2001: 306)

To be clear, in this article, Liverani does not suggest any direct dependence between the Idrimi narrative and EA 17 in drawing the comparison between the two texts. Rather, he instead argues for "a Mitannian court style in story-telling and (hi)story-writing, with the young king as hero" (Liverani 2001: 306), in which both the Idrimi narrative and Tushratta's letter participate.

Of course, to say that the Idrimi narrative belongs to a Mittani court style only on the basis of its commonalities with EA 17 would be a tautology, since it is the Idrimi narrative that shaped Liverani's reading of EA 17 in the first place. Therefore, it is important to emphasize that it is the details of lines 13-14 in the narrative (in which Idrimi begins his adventures with his horse, chariot, and squire, as discussed above) that bear the weight of identifying Idrimi as a maryannu. The parallels with the narrative of Tušratta's life in his letter to the pharaoh support this claim because they define a broader literary context for the Idrimi narrative that was at home in the courts of Mittani Empire and thus emphasize his portrayal not just as an aristocrat but as a Mittanian aristocrat.

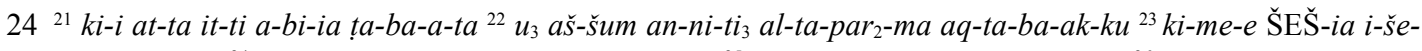
em-me-šu-nu-ma ${ }^{24} u_{3} i-h a-a d-d u$ a-bu-ia i-ra-'a-am-ka ${ }^{25} u_{3}$ at-ta ap-pu-na-ma a-bu-ia ${ }^{26}$ ta-ra-'a-am-šu $u_{3} a$ -

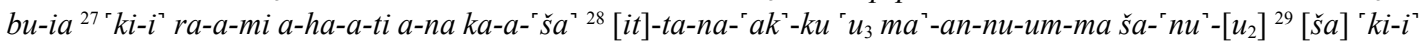
$\left.k a-a-{ }^{r} \check{s} a\right\urcorner$ it-ti a-bi-ia.

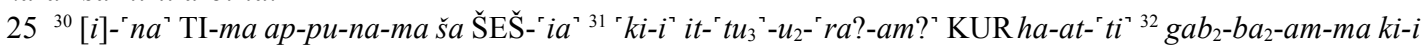

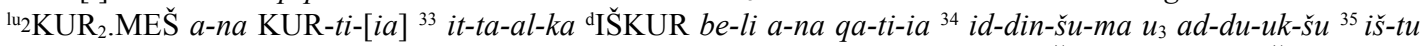

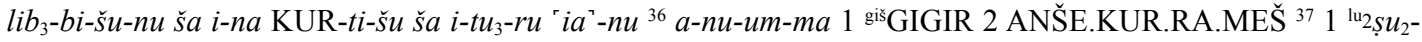
ha-ru $1{ }^{\text {munus } s u_{2}-h a-a r-t u_{4}{ }^{38} \check{s} a} h u-u b-t i ~ s ̌ a ~ K U R ~ h a-a t-t i ~ u l-t e-b i-l a-a k-k u$.
} 
Identifying this home for the Idrimi narrative complicates the comparisons drawn in the scholarship and discussed above between the Idrimi text(s) and various stories from the Hebrew Bible. However, it does not mean that West Semitic linguistic features are absent from the text(s) entirely. The language of the Idrimi text(s) and inscriptions have been the subject of much scholarly attention owing to, as Kathryn Medill (2019: 243) tactfully put it, their "non-standard Akkadian grammar and paleography." For instance, an obvious non-normative grammatical feature in the inscriptions is the occasional use of the Akkadian stative "to refer to a single event," as Smith (1949: 37) observed already in the original edition. Furthermore, the statives often appear in clause initial position when they are used this way:

${ }^{3} i-n a^{\mathrm{uru}} h a-l a-a b^{\mathrm{ki}} \mathrm{E}_{2} a-b i-i a^{4} m a-s ̌ i-i k-t u_{2} i t-t a b-\check{s} i u_{3}$ hal-qa $\boldsymbol{a}_{3}-\boldsymbol{n u} / \mathrm{IGI}^{5} \mathrm{LU}_{2}$.HA ${ }_{2}{ }^{\text {uru }} e^{!}-m a r^{\mathrm{ki}} a-h a-t e$.

$\mathrm{HA}_{2}{ }^{6}[\check{s}]$ a um-mi-ia $u_{3} \boldsymbol{a s ̌ - b a - n u} a-n a$ uru $e-m a r^{\mathrm{ki}}$, "In Aleppo, the house of my father, a bad thing

occurred, so we fled before the Emarites, sisters [o]f my mother, and settled at Emar."

In this passage, the 1c.pl. Akkadian statives halqānu and ašbānu are not used normatively because they are clause-initial and describe punctual, past actions. For these reasons, Smith (1949: 37) interpreted them as instances of West Semitic linguistic influence, whereby Akkadian statives were deployed as West Semitic suffix conjugation verbs, and this position has been maintained by a number of subsequent scholars; see, for example, Aro (1954: 364), Giacumakis (1970: 54), Greenstein \& Marcus (1976: 70-71), and Arnaud (1998: 183).

However, in the same year that the last of these articles appeared, so did one by Ignacio Márquez Rowe (1998), in which this scholar mounted a vigorous challenge to this by now consensus position and attempted to explain the non-normative use of statives in the inscriptions as instances of Hurrian, not West Semitic, linguistic influence. On the face of it, Hurrian influence on the language of the inscriptions might actually be expected, given the extensive Hurrian influence on the language of the legal texts from Late Bronze Age Alalah (for a good example, see AlT 16 [36.2] and Niedorf's (2008: 412-417) comments to the text). Indeed, some of those legal texts were even were written by a scribe, Šarruwa, who bears the same Hurrian name as the scribe who takes credit for the body inscription at its end (lines 98-99; Nadav Na'aman (1980) has explored a connection between the two Šarruwa's). To Márquez Rowe (1998: 75), the use of Akkadian statives as finite verbs made the best sense in a Hurrian milieu: "a Hurrian scribe would generally choose the Akkadian permansive - as a nominal base bound with pronominal suffixes - as his predilect verbal form." In support of this claim, Márquez Rowe (1998: 75) pointed to the Akkadian texts from Late Bronze Age Nuzi, where "the prevalent use of the permansive in Nuzi as a result of Hurrian influence was already pointed out by Wilhelm (1970: 70-77)." So too Márquez Rowe explained the clause-initial word order in light of Hurrian, where, in his words, "The verb in first position can be found as a means of topicalization and, more importantly, it can also mark the subordinate clause whenever it ends in the connective $=a n$ and follows immediately another verbal form. This Hurrian normal construction thus provides resultative force to the second, subordinate, clause" (Márquez Rowe 1998: 71-72). Márquez Rowe explicitly cited the lines from Idrimi's body inscription quoted above as an example of the influence of this feature of the Hurrian language on the Akkadian of Late Bronze Age Alalah.

If this non-normative feature of the Akkadian of the Idrimi inscriptions-statives employed as finite verbs - has thus been explained in two ways, as examples of West Semitic and Hurrian 
linguistic influence, other non-normative features have not been satisfactorily explained at all. Chief among these are hybrid verbal forms, which have both the Akkadian verbal prefix appropriate for a tense conjugation verb and also the suffix appropriate for a stative. So, for example, we find the verb form urtabbi' $\bar{a} k u$, "I was made big," in line 26 of the body inscription instead of the expected Dt preterite urtabbi or stative rutabbâku. The hybridity has been interpreted different ways in the scholarship. For instance, Giacumakis (1970: 34) did not want to recognize a 1 c.s. stative suffix at all and preferred to analyze it instead as the $2 \mathrm{~m}$.s. dative suffix $-k u(m)$, presumably with the preceding /a/-vowel understood to be the ventive. But a second person form makes little contextual sense in this passage. On the other hand, Durand (2011: $138 \mathrm{n}$. 131) proposed seeing a particle $\bar{a} k u$, "une forme enclitique de anâku (non comme un élargissement d'une forme akkadienne finie au moyen d'un affixe de conjugaison ouestsémitique, $[\ldots]$ ce qui permet de distinguer entre $3^{\mathrm{e}}$ et $1^{\mathrm{e}}$ personnes de la forme $\mathrm{D}(=\mathrm{II})$ ou $\mathrm{G}$ avec indécision de lecture." However, as Medill (2019: 248) subsequently pointed out:

\footnotetext{
Durand's hypothesis lacks support elsewhere in the text. If the ISI[=Idrimi Statue Inscription] scribe's use of $-\bar{a} k u$ was meant to disambiguate the person reference of preterite verbs, one wonders why uzakki (line 28) and ušarkibšunu (line 31) [...] did not merit disambiguation [...] yet ețēku in line 33 is parallel to a clearly first-singular verb, and it still receives the suffix. In short, Durand's suggested "disambiguation" rule requires too many exceptions to be proven from the data available in the inscription.
}

Also quite important for any discussion of the language of the Idrimi inscriptions are a handful of verbs that possess a suffix -üna though with the final vowel typically elided. For instance, the verb in line 24 that is written as $i-m u-r u-u n-n i-m a$ and is used when Idrimi is recognized by his countrymen in exile is clearly a form of amāru, "to see." While all scholars treating the line have understood the /u/ suffix to mark the $3 \mathrm{~m}$.pl. subject, there has been no consensus on the following /nni/: Smith (1949: 96) described the suffix in his glossary as the 1 c.s. accusative pronominal suffix -ni; Greenstein and Marcus (1976: 75) saw "a misused subjunctive -ūni inherited from Old Assyrian"; Dietrich and Loretz (1981: 213) suggested the common form of the 1 c.s. accusative pronominal suffix where it is preceded by the ventive after the $3 \mathrm{~m} . \mathrm{pl}$. suffix (-ninni) and, citing Neo-Assyrian parallels, considered the initial $/ \mathrm{n} /$ to have elided and $\bar{u}$-inni to have been realized as -ūnni; and Durand (2011: $137 \mathrm{n} .129)$ analyzed the verb as imuru-na-ni, with the vowel of the West Semitic energic -(n)na- suffix having been elided.

The last three interpretations are presented in a helpful tabular form by Medill (2019: 250 Table 3), who also adds her own interpretation of this suffix and other examples in the body inscription as "borrowed Northwest Semitic suffixes from the imperfect conjugation" (Medill 2019: 249). As Medill (2019: 249-250) explains, in the Canaano-Akkadian code used in the Amarna letters by Levantine scribes in their missive to the Egyptian court, "West Semitic imperfect affixes" were attached "to Akkadian bases to create hybrid imperfect forms [...]. For third masculine plural imperfect verbs, a suffix -üna is characteristic" (on these forms in general, see Rainey 1996: 43-45; Baranowski 2016: 83-84). For instance, in a letter from Byblos the suffix -üna is attested to the Akkadian G present base inammuš as a marker of the 3 m.pl. in the statement la-a yi-na-mu-šu-na [a]-bu-tu-ka iš-tu'a-[bu-ti-ia], "your [fo]refathers were not deserting [my] fo[refathers]" (EA 109 obv. 7-8; see Medill 2019: 250 on this text and for a discussion of the absence of the Canaanite prefixes $t i$ - or $y i$ - in the Idrimi inscriptions more generally). 
What commends Medill's interpretation in particular is that she is able to show that the other non-normative verb forms in the Idrimi inscriptions, described above, also have parallels in the Canaano-Akkadian code of the Levantine Amarna letters. Akkadian statives are frequently deployed as West Semitic suffix conjugations verbs in the Amarna letters, more often with the Canaanite 1 c.s. suffix $-(\bar{a}) t i$ but also with Akkadian -āku (Medill 2019: 248; see also Rainey 1996: 283-287; Baranowski 2016: 62-63). So, for example, in a letter probably from Tell Yokneam, we find the Akkadian stative qabâku used as a perfect verb in the statement $g a b_{2}-b i$ mi-im-mi $i_{3}[\check{s} a i \check{s}]$-me qa-ba-ku [a-na LUGAL]'EN-ia, "The totality of what[ever I he] ard, I recounted [to the king], my lord" (EA 259 obv. 6-b.e. 1). And a number of verbs in the Levantine Amarna letters appear primarily, or even exclusively, in hybrid forms (Medill 2019: 248; see also Rainey 1996: 317-346), such as in a letter from Byblos where the verbal form irtìhat is inflicted in its prefix and infixed -t- like a verb in the perfect tense and in its suffix like a 3 f.s. stative (urugub-la i-na i-de-ni-še ir-ti-ha-at a-na ia-ši , "the city of Byblos alone remains to me" (EA 124 obv. 9-10)).

Explaining the non-normative verb forms in the Idrimi inscriptions as manifestations of a Northwest Semitic-Akkadian code parallel to the Canaano-Akkadian of the Levantine Amarna letters accounts for these forms as elements of a single system and not by reference to a hodgepodge of ad hoc explanations (on the Idrimi inscriptions' Northwest Semitic-Akkadian code as distinct from Canaano-Akkadian, see Medill 2019: 255). And to return to the debate about the language of the Idrimi inscriptions, as described above, it means that we can affirm that the language shows the influence of West Semitic and not Hurrian.

I stated above in the introduction to this article that the Idrimi inscriptions, created and displayed at Alalah, and materializing text(s) intended for consumption by a local audience have the potential to reflect that audience's values. Subsequently, I identified that audience as the nobility of Late Bronze Age Alalah, c.1400-1350 BC. Having looked at the content and language of the text(s) in the following two sections of this article, what, then, can we infer about this audience's values? From the text(s)' decision to portray the protagonist as a maryannu, the nobility of Late Bronze Age Alalah seems to have been thoroughly socialized into the Mittani worldview. Yet, even if for a variety of reasons many of its members bore Hurrian names and probably spoke Hurrian, the local elite seem not just to have spoken a Northwest Semitic language but also to have esteemed this language as well. ${ }^{26}$ We saw at the beginning of this article that the social and political dimensions of the Mittani imperial vision for its periphery mixed top-down and bottom-up approaches; for instance, policy issued from the empire's center but received a local expression in its implementation. To the extent that the Idrimi text(s) reflect the ideology of the local elites of Late Bronze Alalah, we see a similar mixture of top-down and bottom-up in that ideology: these men who had influence in a small kingdom at the western reaches of the Mittani Empire found appeal in the story of a maryannu who "left by chariot for the desert" to make his fortune, yet one that was told in the recognizable Northwest Semitic morpho-syntactic

\footnotetext{
26 For Hurrian as the spoken language at Late Bronze Age (Level IV) Alalah, see Márquez Rowe 1998; for arguments in favor of a West Semitic vernacular, see Arnaud 1998, especially 183-184. Reviewing these articles and other earlier literature, von Dassow (2008: 75) has concluded: "Hurrian was one of the main languages spoken at Alalah during the period of Level IV, the other being a local West Semitic dialect."
} 
rhythms of home. An imperial ideal thus received local expression. Hopefully, future work on the ideological dimensions of empire under the Mittani can elaborate whether this dynamic that we see at work in the Idrimi text(s) is the product of a deliberate Mittanian policy, an unconscious internalization of imperial values, or both.

\section{REFERENCES}

Ando, Clifford 2000. Imperial Ideology and Provincial Loyalty in the Roman Empire. Berkeley: UC Press.

Arnaud, Daniel 1998. Le dialecte d'Alalah: un examen préliminaire. Aula Orientalis 16: 143-186.

Aro, Jussi 1954. Remarks on the Language of the Alalakh Texts. Archiv für Orientforschung 17: 361-365.

Baranowski, Krzysztof 2016. The Verb in the Amarna Letters. (Languages of the Ancient Near East 6) Winona Lake, IN: Eisenbrauns.

Borger, Rykle 1968. Die Statueinschrift des Idrimi von Alalach (um 1400 v. Chr.). In: K. Galling (ed.), Textbuch zur Geschichte Israels: 21-24. Tübingen: Mohr.

Brown, Stephanie H. 2018. Dining under Assyrian Rule: Foodways in Iron Age Edom. In: C.W. Tyson \& V. HermanN (eds), Imperial Peripheries in the Neo-Assyrian Empire: 150-176. Louisville, CO: University Press of Colorado.

Bunnens, Guy 1978. Ilim-ilimma, fils de Tuttu 'bourgeois-gentilhomme' d'Alalakh au Xve s. av. n.e.. Akkadica 10: 2-15.

CAnciK-Kirschbaum, Eva, Nicole Brisch \& Javier Eidem 2014. Introduction. In: E. CANCIK-Kirschbaum, N. Brisch \& J. Eidem (eds), Constituent, Confederate, and Conquered Space: The Emergence of the Mittani State (Berlin Studies of the Ancient World 17): 1-8. Berlin: De Gruyter.

von Dassow, Eva 2002. Lists of People from the Alalah IV Administrative Archives. Ugarit-Forschungen 34: 835-911.

von Dassow, Eva 2008. State and Society in the Late Bronze Age: Alalah under the Mittani Empire. (Studies on the Civilization and Culture of Nuzi and the Hurrians 17) Bethesda, MD: CDL Press.

von Dassow, Eva 2014. Levantine Polities under Mittanian Hegemony. In: E. CANCIK-Kirschbaum, N. Brisch \& J. EIDEM (eds), Constituent, Confederate, and Conquered Space: The Emergence of the Mittani State (Berlin Studies of the Ancient World 17): 11-32. Berlin: De Gruyter.

von Dassow, Eva 2020. Alalah between Mittani and Hatti. Asia Anteriore Antica: Journal of Ancient Near Eastern Cultures 2: 193-226.

Dietrich, Manfried \& Oswald LoRETZ 1969. Die soziale Struktur von Alalah und Ugarit (II): Die sozialen Gruppen hupšenamê, haniahhe-ek̂u, ehele-šüzubu und marjanne nach Texten aus Alalah IV. Die Welt des Orients 5: 57-93.

Dietrich, Manfried \& Oswald Loretz 1981. Die Inschrift des Königs Idrimi von Alalah. Ugarit-Forschungen 13: 201-278.

Dietrich, Manfried \& Walter Mayer 1996. Hurritica Alalahiana (I). Ugarit-Forschungen 28: 177-188.

Durand, Jean-Marie 2011. La fondation d'une lignée royale syrienne: Le geste d'Idrimi d'Alalah. In: J.-M. Durand, T. Römer \& M. LANGLoIs (eds), Le jeune héros: Recherches sur la formation et la diffusion d'un thème littéraire au Proche-Orient ancien (Orbis Biblicus et Orientalis 250): 94-150. Fribourg: Academic Press.

Fink, Amir Sumaka'i 2010. Late Bronze Age Tell Atchana (Alalakh): Stratigraphy, Chronology, History. (BAR International Series 2120) Oxford: Archaeopress.

Giacumakis, George 1970. The Akkadian of Alalah. The Hague: Mouton.

Greenstein, Edward L. 2015. The Fugitive Hero Narrative Pattern in Mesopotamia. In: J.J. Collins, T.M. Lemos \& S. Olyan (eds), Women, Worship, and War: Essays in Honor of Susan Niditch (Brown Judaic Studies 357): 17-35. Providence: Brown Judaic Studies.

GreEnstein, Edward L. \& David Marcus 1976. The Akkadian Inscription of Idrimi. Journal of the Ancient Near Eastern Society 8: 59-96.

Homan, Zenobia 2020. Mittani Palaeography. (Cuneiform Monographs 48) Leiden: Brill.

KLENGEL, Horst 1981. Historischer Kommentar zur Inschrift des Idrimi von Alalah. Ugarit-Forschungen 13: $269-278$.

LAUINGER, Jacob 2019. Discourse and Meta-discourse in the Statue of Idrimi and Its Inscription. MAARAV 23: 19-38.

Liverani, Mario 1972. Partire sul carro, per il deserto. Annali dell'Istituto Orientale di Napoli 32: 403-415. 
LiVerani, Mario 1974. L'histoire de Joas. Vetus Testamentum 24: 438-453.

Liverani, Mario 2001. Mesopotamian Historiography and the Amarna Letters. In: T. Abusch, C. Noyes, W. Hallo \& I. WINTERS (eds), Proceedings of the XLV Rencontre Assyriologique Internationale, I: Historiography in the Cuneiform World: 303-311. Bethesda, MD: CDL Press.

Liverani, Mario 2004. Myth and Politics in Ancient Near Eastern Historiography. Ithaca: Cornell University Press.

MÁrquez Rowe, Ignacio 1998. Notes on the Hurro-Akkadian of Alalah in the Mid-Second Millennium BCE. Israel Oriental Studies 18: 63-78.

de Martino, Stefano 2015. Mittanian Hegemony in Western and Central Syria. In: P. Pfälzner \& M. Al-MaqdisSI (eds), Qatna and the Networks of Bronze Age Globalism (Qatnien Studien: Supplementum 2): 25-31. Wiesbaden: Harrassowitz.

De Martino, Stefano 2018. Political and Cultural Relations between the Kingdom of Mittani and Its Subordinated Polities in Syria and Southeast Anatolia. In: A. Gianto \& P. Dubovský (eds), Changing Faces of Kingship in Syria-Palestine 1500-500 BCE (Alter Orient und Altes Testament 459): 37-50. Münster: Ugarit.

MAYER-Opificius, Ruth 1981. Archäologischer Kommentar zur Statue des Idrimi von Alalah. Ugarit-Forschungen 13: 279-290.

Medill, Kathryn 2019. The Idrimi Statue in its Late Bronze Age Scribal Context. Bulletin of the American Schools of Oriental Research 382: 243-259.

NA' AmAn, Nadav 1980. A Royal Scribe and His Scribal Products in the Alalakh IV Court. Oriens Antiquus 19: 107-116.

NiEdorf, Christian 2008. Die mittelbabylonischen Rechtsurkunden aus Alalah (Schicht IV). (Alter Orient und Altes Testament 352) Münster: Ugarit.

Nougayrol, Jean 1951. Review of The Statue of Idri-mi, by Sidney Smith. Revue d'Assyriologie 45: 151-154.

OAtLey, Keith 1994. A Taxonomy of the Emotions of Literary Response and a Theory of Identification in Fictional Narrative. Poetics 23: 53-74.

OAtley, Keith 1999. Meetings of Minds: Dialogue, Sympathy, and Identification in Reading Fiction. Poetics 29: 439-454.

Oller, Gary 1977. The Autobiography of Idrimi: A New Text Edition with Philological and Historical Commentary. $\mathrm{PhD}$ dissertation, University of Pennsylvania.

Oppenheim, A. Leo 1955. Review of The Statue of Idri-mi, by Sidney Smith. Journal of Near Eastern Studies 14: 199-200.

RaIney, Anson F. 1996. Canaanite in the Amarna Tablets: A Linguistic Analysis of the Mixed Dialect Used by the Scribes from Canaan, II: Morphosyntactic Analysis of the Verbal System. (Handbook of Oriental Studies 25) Leiden: Brill.

SASSON, Jack 1981. On Idrimi and Šarruwa, the Scribe. In: M.A. Morrison \& D. Owen (eds), Studies on the Civilization and Culture of Nuzi and the Hurrians in Honor of Ernest R. Lacheman (Studies on the Civilization and Culture of Nuzi and the Hurrians 1): 309-324. Winona Lake, IN: Eisenbrauns.

Schwartz, Glenn M. 2014. Reflections on the Mittani Emergence. In: E. CAnCiK-Kirschbaum, N. Brisch \& J. Eidem (eds), Constituent, Confederate, and Conquered Space: The Emergence of the Mittani State (Berlin Studies of the Ancient World 17): 265-277. Berlin: De Gruyter.

Sмith, Sidney 1949. The Statue of Idri-mi. (Occasional Publications of the British Institute of Archaeology in Ankara 1) London: British Institute of Archaeology in Ankara.

VIDAL, Jordi 2012. Summaries on the Young Idrimi. Scandinavian Journal of the Old Testament 26: 77-87.

WeEden, Mark 2011. Hittite Logograms and Hittite Scholarship. (Studien zu den Boğazköy-Texten 54) Wiesbaden: Harrasowitz.

Wilhelm, Gernot 1970. Untersuchungen zum Hurro-Akkadischen von Nuzi. (Alter Orient und Altes Testament 9) Kevelaer: Butzon \& Bercker.

Yener, Kutlu Aslihan, Murat Akar \& Mara T. Horowitz (eds) 2019. Tell Atchana, Alalakh, II: The Late Bronze II City: 2006-2010 Excavation Seasons. Istanbul: Koç University Press. 